\section{A Dozen Years of Service to Higher Education}

$\mathrm{T}$ his is the 5oth issue of International Higher Education. Our first issue appeared in the spring of I995, almost I3 years ago. Our commitment then, as now, is to provide thoughtful analysis of contemporary events in higher education worldwide and information on current developments, especially in countries that do not receive much attention. We have a special concern with the broad issues of globalization and internationalization. Because of our sponsorship by a Jesuit university, we have been interested in issues relating to Catholic and Jesuit education worldwide. Ours has been an effort at network building and information provision.

We have focused attention on themes and countries sometimes neglected in discussions of higher education. IHE has from the beginning had a special interest in developing countries-especially on how the developing world can cope with international trends largely determined by the major academic powers. Among the topics we have emphasized over the years have been private higher education (our collaboration with the Program of Research on Private Higher Education-PROPHE at the University at Albany has been especially important), corruption issues, internationalization and globalization, and others. A combination of independent and often critical analysis, focus on central issues for higher education worldwide, and short but incisive articles has proved to be a successful strategy.

$I H E$ is aggressively noncommercial. We do not charge for a subscription. We are always happy to provide permission, without any fee, to publications interested in reprinting our articles. Our Web site is available without charge and is linked with many other Web sites focusing on higher education. We accept no advertising in any of our publications or on our Web site. We have been able to do this work because of support from the Ford Foundation and from Boston College.

International Higher Education is by now recognized as a source of information and analysis worldwide. We mail to readers in I54 countries. IHE is available on our Web site and is widely used. We have been careful to archive all of the back issues and have indexed them so that researchers and others can have easy access. IHE articles are widely cited in the literature and are often reprinted by journals in many parts of the world. We currently work with publications in Mexico, the United Kingdom, the United States, and China that regularly reprint our articles. IHE is translated into Arabic, thanks to Google, and we are working on starting a Chinese-language edition in collaboration with the Shanghai Jiao Tong University Institute of Higher Education.

We have asked colleagues who have been associated with International Higher Education to reflect on some key trends in higher education in an international perspective over the past decade of our publication. Several of these articles follow. Additional contributions will be published in the coming issues. We look forward to our rooth issue!

Philip G. Altbach, Editor

\section{Globalization and Forces for Change in Higher Education}

\section{Philip G. Altbach}

Philip G. Altbach is J. Donald Monan SJ professor of higher education and director of the Center for International Higher Education at Boston College.

W hat is globalization and how does it affect higher education policy and academic institutions? The answer is deceivingly simple and the implications are surprisingly complex. For higher education, globalization implies the broad social, economic, and technological forces that shape the realities of the 2Ist century. These elements include advanced information technology, new ways of thinking about financing higher education and a concomitant acceptance of market forces and commercialization, unprecedented mobility for students and professors, the global spread of common ideas about science and scholarship, the role of English as the main international language of science, and other developments. Significantly, the idea of mass access to higher education has meant unprecedented expansion of higher education everywhere-there are about I34 million students in postsecondary education worldwide, and many countries have seen unprecedented and sustained expansion in the past several decades. These global trends are for the most part inevitable. Nations, and academic institutions, must constructively cope with the implications.

Contemporary inequalities may in fact be intensified by globalization. Academic systems and institutions that at one time could grow within national boundaries now find themselves competing internationally. National languages compete with English even within national borders. Domestic academic journals, for example, often compete with international publications within national academic systems, and scholars are pressured to publish internationally. Developing countries are at a significant disadvantage in the new globalized academic system, but smaller academic systems in rich countries also face problems. In a ranking-obsessed world, the top universities are located predominantly in the United States, the United Kingdom, and a few other rich countries. The inequalities of the global age are just as profound and in part more complex than the realities of the era of colonialism.

Academic systems will need to cope with the key realities of 
the first part of the 2ist century for higher education.

\section{Massification}

Massification is without question the most ubiquitous global influence of the past half century or more. The United States had the first mass higher education system, beginning as early as the I920s. Europe followed in the I960s, and parts of Asia a decade or so later. The developing countries were the last to expand. Most of the growth of the 2Ist century is taking place in developing and middle-income countries. There are now more than I40 million students in postsecondary education worldwide, and this number continues to expand rapidly. North America, Europe, and a number of Pacific Rim nations now enroll 60 percent or more of the relevant age group in higher education. What has massification brought?

\section{Massification is without question the most ubiqui-} tous global influence of the past half century or more.

Public good vs. private good. Stimulated in part by the financial pressures of massification and also by broader changes in economic thinking, including the neoliberal agenda, higher education is increasingly considered in economic terms a private good-a benefit accruing mainly to individuals who should pay for it rather than a public good that contributes benefits to society and thus should be financially supported by the state.

Access. Postsecondary education has opened its doors to previously excluded population groups-women; people from lower socioeconomic classes; previously disadvantaged racial, religious, and ethnic groups; and other populations. While many countries still contain disparities in enrollment, massification has clearly meant access and thus upward mobility and increased earning potential. Access also greatly expanded the skills of populations, making economic expansion possible.

Differentiation. All mass higher education systems are differentiated systems. Institutions serve varied missions, with differing funding sources and patterns and a range of quality. Successful academic systems must ensure that the various segments of the system are supported and sustained. While research universities need special attention, mass-access institutions do as well.

Varied funding patterns. For most countries, the state has traditionally been the main funder of higher education. Massification has placed great strains on state funding, and in all cases governments no longer believe they can adequately fund mass higher education. Other sources of funding need to be found-including student tuition and fees (typically the largest source), a variety of government-sponsored and private loan programs, university income generating programs (such as industry collaboration or consulting), and philanthropic support.

Decline in quality and conditions of study. On average in most countries, the quality of higher education has declined. In a mass system, top quality cannot be provided to all students. It is not affordable, and the ability levels of both students and professors necessarily become more diverse. University study and teaching are no longer a preserve for the elite-both in terms of ability and wealth. While the top of a diversified academic system may maintain its quality (although in some countries the top sector has also suffered), the system as a whole declines.

\section{Peaks and Valleys in Global Science and Scholarship}

A variety of forces have combined to make science and scholarship global. Two key elements are responsible. The growth of information technology (IT) has created a virtual global community of scholarship and science. The increasing dominance of English as the key language of communicating academic knowledge is enhanced by IT. Global science provides everyone immediate access to the latest knowledge. Thus, everyone must compete on the same playing field to participate in research and discovery. It is as if some teams (the wealthiest universities) have the best training and equipment, while the majority of players (universities in developing countries and smaller institutions everywhere) are far behind. There is increased pressure to participate in the international big leagues of science-such as publishing in recognized journals in English. Thus, while IT makes communication easier it tends to concentrate power in the hands of the "haves" to the disadvantage of the "have nots." National or even regional academic communities, located in the valleys of higher education, are overshadowed by the peaks of the global academic powers that dominate the new knowledge networks.

The increasing dominance of English as the key language of communicating academic knowledge is enhanced by IT.

\section{Globalization of the Academic Marketplace}

More than 2 million students are studying abroad, and it is estimated that this number will increase to 8 million by 2025 . Many others are enrolled in branch campuses and twinning programs. There are many thousands of visiting scholars and postdocs studying internationally. Most significantly, there is a global circulation of academics. Ease of transportation, IT, the use of English, and the globalization of the curriculum have tremendously increased the international circulation of academic talent. Flows of students and scholars move largely from South to North-from the developing countries to North America and Europe. And while the "brain drain" of the past has become more of a "brain exchange," with flows of both 
people and knowledge back and forth across borders and among societies, the great advantage still accrues to the traditional academic centers at the expense of the peripheries. Even China, and to some extent India, with both large and increasingly sophisticated academic systems, find themselves at a significant disadvantage in the global academic marketplace. For much of Africa, the traditional brain drain remains largely a reality.

\section{CONCLUSION}

Thomas Friedman's "flat world" is a reality for the rich countries and universities. The rest of the world still finds itself in a traditional world of centers and peripheries, of peaks and valleys and involved in an increasingly difficult struggle to catch up and compete with those who have the greatest academic power. In some ways, globalization works against the desire to create a worldwide academic community based on cooperation and a shared vision of academic development. The globalization of science and scholarship, ease of communication, and the circulation of the best academic talent worldwide have not led to equality in higher education. Indeed, both within national academic systems and globally, inequalities are greater than ever.

\section{The Growing Accountability}

\section{Agenda: Progress or Mixed Blessing?}

\section{JAMIL SALMI}

Jamil Salmi is the tertiary education coordinator of the World Bank, Washington, DC, USA. E-mail: jsalmi@worldbank.org.

$\mathrm{C}$ ompared to the well-established tradition of accreditation in the United States, public universities in many countries have typically operated in a very autonomous manner. In the francophone countries of Africa, for example, institutions enjoy full independence in the selection (election) of their leaders and complete management autonomy. They do not have to answer for their inefficient performance. In several Latin American countries, the constitution entitles public universities to a fixed percentage of the annual budget that they are free to use without accountability. Some countries do not even have a government ministry or agency responsible for steering or supervising the tertiary education sector.

In the past decade, however, accountability has become a major concern in most parts of the world. Governments, parliaments, and society at large are increasingly asking universi- ties to justify the use of public resources and account more thoroughly for their teaching and research results. This undertaking may include many forms: legal requirements such as licensing, accreditation, assessment tests to measure what students have learned; professional examinations; performancebased budget allocation; and governing boards with external participants. Sometimes the press itself enters the accountability arena with its controversial league tables.

\section{The Accountability Agenda}

Nobody can argue that universities should not be accountable. First, governments are responsible for establishing a regulatory framework to prevent fraudulent practices. Accusations of

Governments, parliaments, and society at large are increasingly asking universities to justify the use of public resources and account more thoroughly for their teaching and research results.

flawed medical research in the United Kingdom, reports of Australian universities cutting corners to attract foreign students, and the student loan scandal in the United States show the need for vigilance, even in countries with strong accountability mechanisms. Second, universities should legitimately be held accountable for their use of public money and the quality of their outputs (graduates, research, and regional engagement). The evolution toward increased accountability is reflected in the expansion in the number of stakeholders, themes under scrutiny, and channels of accountability.

The teaching staff has traditionally been the most powerful group in universities, especially where the head of the institution is democratically elected. Even at Harvard, the demise of President Summers in 2006 was largely due to the opposition of some professors. But today university leaders must at the same time meet the competing demands of several groups of stakeholders: (a) society at large; (b) government, which can be national, provincial, or municipal; (c) employers; (d) the teaching staff; and (e) the students themselves. Even within government structures, demands for accountability are coming from new actors-as has happened in Denmark, where responsibility for the universities' sector is now with the Ministry of Technology.

The pressure for compliance comes through an increasingly broad variety of instruments. Government controls take the form of compulsory requirements, such as accreditation, performance indicators, and mandatory financial audits. They can also operate indirectly through financial incentives such as performance-based budget allocation. In countries with a student loan system, these loans are usually available only for studies in bona fide institutions. Innovative funding approaches-such as the voucher systems recently established in the state of Colorado and in several former Soviet Union republics 